\title{
Hallo traveler, how happy are you? Psychological well-being traveler ditinjau dari big-five personality dan traveling type
}

\author{
Lusy Asa Akhrani i*, Muhammad Afif Alhad ${ }^{2}$, Asalia Najib ${ }^{3}$, Hanna Almira ${ }^{4}$, Syarifah Ayu Maulida ${ }^{5}$, \\ Chintya Fatima Dewi ${ }^{6}$, Candrika Yolanda ${ }^{7}$ \\ Univeritas Brawijaya, Indonesia
}

\begin{tabular}{l}
\hline Info Artikel \\
\hline Sejarah Artikel: \\
Diterima \\
I 4 Februari 2020 \\
Direview \\
I7 April 2020 \\
Disetujui \\
28 September 2020 \\
Dipublikasikan \\
30 September 2020 \\
\hline Keywords: Big-five \\
personality, psychological \\
well-being, tipe traveling
\end{tabular}

\begin{abstract}
Abstrak
Berwisata telah menjadi kebutuhan bagi sebagian orang dimana aktivitas tersebut dapat menghilangkan kejenuhan, meningkatkan daya kreatif serta memberikan relaksasi bagi individu. Wakil Menteri Pariwisata dan Ekonomi Kreatif, Sapta Nirwandar, menyampaikan bahwa wisata tak hanya memberikan stimulasi untuk kesehatan tetapi juga memberikan dampak positif bagi perekonomian.Aktivitas pariwisata di Indonesia mulai berkembang dan telah menjadi gaya hidup tersendiri dalam masyarakat. Penelitian ini bertujuan untuk mengetahui peran personality dan tipe traveling yang dipilih traveler dengan psychological well-being traveler. Penelitian ini menggunakan tiga skala penelitian yaitu skala personality yang merujuk pada big five personality, skala tipe traveling dan skala psychological well-being. Penelitian dilakukan secara online disebarkan pada 1558 traveler. Analisis hasil menggunakan multiple linier regression. Hasil penelitian ini menunjukan bahwa big-five personality secara simultan berperan terhadap psychological well-being. Sedangkan psychological wellbeing bila dikaitkan pada tipe traveling menunjukan hasil bahwa secara simultan traveling type memiliki peran terhadap psychological well-being.
\end{abstract}

\section{Hallo Traveler, How Happy are you? Reviewed Psychological Well-Being Traveler From Big-Five Personality And Traveling Type}

Travelling has become a necessity for some people where these activities can eliminate boredom, increase creative power and provide relaxation for individuals (Kalebos, 2016). Deputy Minister of Tourism and Creative Economy, Sapta Nirwandar, said that tourism not only provides stimulation for health but also has a positive impact on the economy (Farhan, 2012). Tourism activities in Indonesia are starting to develop and have become a lifestyle in its own right. This study aims to determine the role of personality and travelling type by travellers with psychological well-being traveller. This study uses three research scales, namely personality scale, which refers to McCrae and Costa's big five personality, Scott and Mowen's travelling type scale and Ryff's psychological well-being scale. The research carried out online was distributed to 1558 travellers. Analysis of the results using multiple linear regression. The results of this study indicate that bigfive personality simultaneously plays a role in psychological well-being. Whereas psychological well-being when it is related to the type of travelling shows the results that are simultaneously travelling type has a role in psychological wellbeing.

*Alamat korespondensi:

Fisip Universitas Brawijaya, Gedung A, Lantai 4, Malang

[lusyasa@ub.ac.id] 


\section{Pendahuluan}

Pariwisata merupakan salah satu sektor yang berperan besar dalam hal pendapatan suatu negara. Kementerian Pariwisata (2017) menyatakan bahwa pariwisata berperan melalui penerimaan devisa, pembukaan lapangan kerja dan kesempatan berusaha, dan juga pembangunan infrastruktur yang akhirnya akan mendorong kemajuan sosio-ekonomi negara. World Tourism Organization (UNWTO) (2018) menyatakan bahwa satu dari sepuluh pekerjaan di dunia berasal dari sektor pariwisata. Tingginya pengaruh pariwisata terhadap berbagai aspek dalam perekonomian Indonesia membuat pemerintah beberapa kali mencanangkan program kunjungan ke Indonesia baik untuk wisatawan mancangera maupun domestik. Pemerintah menggunakan slogan "Pesona Indonesia" serta mengadakan berbagai kegiatan dengan harapan masyarakat Indonesia menjadi semakin tertarik untuk berwisata di negaranya sendiri (Kementerian Pariwisata, 2017).

Berwisata didefinisikan sebagai suatu kegitan melakukan perjalanan santai keluar tempat tinggal dan dilakukan diluar rutinintas sehari-hari, telah diakui secara luas sebagai bagian dari kebutuhan hidup manusia (Richard, 1999). Sejalan dengan apa yang dikatakan Hermawan dan Hendrastomo (2017) bahwa di beberapa tahun terakhir, waktu luang banyak dimanfaatkan individu untuk melakukan perjalanan wisata atau yang disebut juga dengan traveling. Suatu perjalanan dikatakan sebagai perjalanan berwisata apabila memiliki syarat: (I) Perjalanan dilakukan dari satu tempat ke tempat lain, diluar tempat kediaman individu tersebut tinggal; (2) Tujuan dari sebuah perjalanan tersebut hanya untuk bersenang-senang dan tidak mencari penghasilan ditempat yang dikunjungi; (3) Peran pelaku perjalanan hanya sebagai konsumen di tempat yang dikunjungi. Menurut Filep dan Pearce (2014) berwisata merupakan salah satu cara untuk meningkatkan kualitas kehidupan individu dan bagi Zhang (2013) kegiatan berwisata atau traveling merupakan kegiatan yang berhubungan kuat dengan kesejahteraan (wellbeing), dimana pada kesempatannya adalah pencarian kualitas rekreasi yang lebih baik ketika kebutuhan dasar manusia telah terpenuhi. Uysal (2015) mengatakan bahwa traveling mempengaruhi kualitas hidup wisatawannya, menghasilkan efek positif bagi waktu luang, keluarga, pekerjaan, kehidupan sosial, rohani, dan masih banyak aspek lainnya (Garces, Pocinho, Jesus, \& Rieber, 2018).

Individu melakukan perjalanan dengan harapan merasakan kenyamanan maupun melepas rasa penat yang diakibatkan oleh aktvitas sehari-hari. Melalui perjalanan, Individu juga banyak mempelajari hal baru. Individu dengan karakter kepribadian yang beragam (Individual Defferences) dalam konteks traveler tentunya juga memiliki keberagaman. Traveller termotivasi untuk melakukan perjalanan (traveling) yang beragam, namun motivasi yang paling dominan yakni lebih kepada kepuasan psikologis Psychological Well-Being (PWB). Kepuasan bisa memiliki banyak arti seperti rasa senang (pleasure), kebahagiaan hidup, hidup bermakna, emosi positif atau bisa juga merasakan kebermaknaan (contentment). Beberapa ilmuwan menggunakan istilah well-being sebagai istilah dari kebahagiaan (happiness). well-being secara konseptual mengacu pada pengalaman dan fungsi psikologis secara optimal. Ryan dan Deci (Primasani, 2005) mengemukakan bahwa ada dua pendekatan dalam menjelaskan mengenai well-being, yaitu pendekatan eudaimonic dan hedonic.

Ryff (1989) mendefinisikan Psychological Well Being (PWB) sebagai sebuah hasil evaluasi atau penilaian seseorang terhadap dirinya yang merupakan evaluasi pengalaman-pengalaman hidupnya. Evaluasi terhadap pengalaman tersebut menyebabkan seseorang individu pasrah terhadap keadaan, hal ini mengakibatkan kesejahteraan psikologisnya menjadi rendah atau dapat dikatakan individu tersebut berusaha untuk memperbaiki hidupnya agar kesejahteraan psikologisnya meningkat. Lebih lanjut Ryff (1889) mendefinisikan Psychological Well Being (PWB) sebagai sebuah kondisi dimana individu memiliki sikap yang positif terhadap dirinya sendiri dan orang lain, dapat membuat keputusan sendiri dan mengatur tingkah lakunya sendiri, bisa menciptakan maupun mengatur lingkungan yang sesuai dengan kebutuhannya atau dapat dikatakan yang sesuai dengan dirinya, serta memiliki tujuan hidup dan membuat hidup mereka 
lebih bermakna serta berusaha dan eksplorasi diri. Motivasi mencapai kebahagiaan dengan melakukan perjalanan menjadi menarik untuk dianalisis dalam perilaku berwisata, mengingat destinasi wisata di Indonesia sangat beragam dan menuntun tipe traveling tertentu.

Destinasi wisata yang ditawarkan oleh Indonesia memiliki jenis yang beragam, mulai dari wisata alam, wisata sejarah, wisata edukasi, hingga wisata budaya. Sebuah penelitian yang dilakukan oleh Hall (1989) menemukan bahwa wisata yang lebih banyak dipromosikan di negara-negara Asia Tenggara adalah wisata alam karena sumber dayanya yang melimpah, dan hal tersebut masih banyak dilakukan oleh negara-negara Asia tenggara termasuk di Indonesia hingga kini. Scott dan Mowen (2007) mengidentifikasi traveling ke dalam empat kategori. Pertama adalah perjalanan luxury travel, yang didefinisikan secara harfiah sebagai gaya perjalanan atau berwisata yang mewah (Popescu \& Olteanu, 2014). Kedua adalah camping travel yang merupakan perjalanan ke lokasi di luar ruangan untuk tujuan berinteraksi dengan alam. Ketiga, hardadventure travel yang didefinisikan sebagai perjalanan dengan tujuan memperoleh pengalaman ekstrem yang memiliki potensi risiko tingkat tinggi di lingkungan luar. Terakhir adalah softadventure travel yang merupakan perjalanan yang memiliki tingkat risiko rendah hingga sedang dan mencakup lingkungan yang nyaman (Scott \& Mowen, 2007). Menurut peneliti masingmasing tipe traveling mampu menghadirkan psychological well being yang berbeda, namun sayangnya penelitian terkait tipe traveling dan psychological well-being belum pernah dilakukan. $\mathrm{Hal}$ ini menjadikan tantangan penelitian untuk meneliti keterkaitan antar kedua variabel.

Penelitian psychological well-being sering dilakukan terkait dengan kepribadian. Kepribadian sendiri merupakan variabel yang kuat dalam memprediksi psychological well-being. Penelitianpenelitian mengenai Big Five Personality menunjukkan bahwa trait merupakan prediktor yang konsisten dalam berbagai macam situasi, khususnya dalam hal ini adalah traveling behaviour. Big Five Personality Theory adalah teori kepribadian yang menyatakan bahwa kepribadian individu tersusun dalam lima buah domain atau trait utama yang telah dibentuk dengan menggunakan analisis faktor (Cervone \& Pervin, 2012). Kelima trait dalam tersebut adalah extraversion (E), agreeableness $(A)$, conscientiousness $(C)$, neuroticism $(N)$, openness to experiences $(O)$. Setiap orang memiliki kecenderungan pada trait tertentu (Friedman \& Schustack, 2008). Berbagai makna traveling, bentuk tipe turis, bentuk gaya traveling, dan sebagainya merujuk pada peran yang dimainkan oleh wisatawan selama merasakannya dan melakukan suatu perjalanan, merupakan konsep terbaru yang telah muncul dalam literatur pariwisata untuk menggambarkan karakteristik perjalanan yang telah stabil diduga dipengaruhi oleh faktor kepribadian yang lebih dalam (Park, Tussyadia, Mazanec \& Fesenmaier, 2010). Melihat kurangnya penelitian semacam ini, cukup mengherankan mengingat kehadiran kepribadian yang reliabel seperti Big Five Personality yang diyakini universal (Mowen, 2000) dapat digunakan untuk lebih memahami wisatawan dan memprediksi kemungkinan perjalanan yang mereka lakukan.

Terdapat beberapa penelitian yang menggunakan keterkaitan serupa Big Five Personality dengan konteks traveling, yakni peran Big Five Personality dengan intensi wisatawan untuk mencari informasi terlebih dahulu di internet terkait tujuan berwisata mereka (Jani, Jang, \& Hwang, 2013) mengatakan bahwa pencarian informasi perjalanan melalui internet bervariasi kecuali pada trait extraversion, dan saluran internet yang digunakan untuk mencari informasi perjalanan juga bervariasi kecuali di conscientiousness. Gretzel (2004) melakukan penelitian mengenai penggunaan Big Five Personality dengan Destination Recomendation System (DRS), menyatakan bahwa hubungan tersebut sangat dapat digunakan. Lalu ada Aaker (1997) yang mengembangkan teori Brand Personality berdasarkan konsep Big Five Personality. Scott dan Mowen (2007) yang serupa mengaitkan Big Five Personality dengan kecenderungan tipe traveling (traveling type propencity) menghasilkan penemuan bahwa trait agreeableness berhubungan positif terhadap Soft Adventure travel. Labbe (2016) melakukan penelitian mengenai Big Five Personality terhadap Cultural Awarness saat berpergian dan menemukan adanya keterkaitan yang signifikan antara 
trait openness dan conscientiousness dengan cultural awareness atau kesadaran akan budaya yang berbeda.

Scott dan Mowen (2007) dalam penelitiannya yang dilakukan di Oklahoma, Amerika, mengamati hubungan yang signifikan antara kecenderungan untuk menjadi adventure traveler dan Big Five Personality. Masih dalam konteks yang sama, Schneider dan Vogt (2012) mencatat keterbukaan terhadap pengalaman (Openness) menjadi faktor pembeda yang signifikan antara hard-adventure dan soft-adventure traveler. Abbate dan Nuovo (2013) berusaha untuk menghubungkan Big Five Personality dan motivasi untuk mengunjungi tempat-tempat keagamaan dengan temuan yang menunjukkan perbedaan antara skor Big Five Personality untuk motif yang berbeda. Jani (2014) pun melakukan studi yang menegaskan bahwa penerapan openness, neuroticism, dan agreeableness berkaitan dengan travel curiosity. Sementara penelitian yang dilakukan oleh Verma, Kumar, dan Chandra (2017) pada traveler yang mengunjungi India menunjukan bahwa hampir seluruh trait dalam Big Five Personality adalah prediktor positif dalam intensi untuk mengunjungi Green Hotel, hanya neurotisism yang tidak signifikan.

Big Five Personality oleh McCrae dan Costa (yang sering digambarkan sebagai kerangka yang bersifat universal untuk mengukur kepribadian individu secara komperhensif (Loundsbury et al., 1999; Gurven et al, 2013; Davies et al., 2018). Seperti namanya, McCrae \& Costa (2003) menjabarkan BFP dengan lima trait yang mewakili sifat dasar manusia. Kelima trait dalam BFP adalah extraversion $(E)$, agreeableness $(A)$, conscientiousness $(C)$, neuroticism $(N)$, openness to experiences $(O)$. Setiap orang digambarkan memiliki kelima trait BFP, namun tiap individu memiliki kecenderungan pada satu trait tertentu (Friedman \& Schustack, 2012). Masing-masing trait terdiri dari facet atau karakteristik yang berbeda-beda dalam mewakili kepribadian. Satu individu dipastikan akan mempunyai karakter-karakter yang berbeda dari individu lainnya, karakteristik yang bertahan lama merupakan cerminan dari kepribadian, dan kebertahanan tersebut juga menunjukan bahwa kepribadian merupakan sesuatu yang relatif stabil (stable) dan dapat diprediksi (predictable) (Fadil \& Loeis, 2016). Meskipun demikian, penelitian yang dilakukan oleh Pullmann, Raudsepp dan Allik (2006) menunjukan bahwa pada remaja usia I2-18 tahun kepribadian masih terus berkembang, sehingga kepribadian baru dapat dikatakan cenderung stabil apabila individu telah berada pada rentang usia dewasa (McCrae \& Costa, 2003). Berdasarkan data yang dimuat dalam berbagai media yang menunjukkan adanya trend kenaikan perjalanan wisata, peneliti merasa perlunya diadakan kajian lebih lanjut mengenai tipe travel traveler Indonesia, kepribadian Big Five Personality dan psychological wellbeing traveler.

Perkembangan wisata di Indonesia sendiri menjadi fenomena tersendiri dimana terjadi penyeragaman tampilan tempat wisata, seolah semua traveller memiliki kesamaan kebutuhan dalam berwisata seperti spof foto, fasilitas yang disediakan, dan tujuan berwisata sehingga wisatawan justru merasakan psychological wellbeing yang tidak sesuai dengan kebutuhan dalam kegiatan berwisata ini. Penelitian ini bisa dimanfaatkan untuk referensi pengembangan lokasi traveling yang banyak tersebar di berbagai destinasi wisata di Indonesia, referensi pemasaran destinasi wisata khususnya untuk traveler berdasarkan tipe kepribadian demi pencapaian psychological well being yang dimiliki oleh para traveler.

\section{Metode}

Sampel dalam penelitian ini berjumlah 1558 yang merupakan warga negara Indonesia, berusia minimal 18 tahun dan menyukai kegiatan travelling. Pemilihan sampel diambil menggunakan teknik purposive sampling berdasarkan kriteria yang telah disebutkan. Peneliti melakukan transadaptasi dan modifikasi pada skala tipe soft-adventure travel propensity. Proses transadaptasi mengacu pada Beaton (2000), namun peneliti melakukan proses tambahan yakni focused group discussion (FGD) dengan melibatkan contoh subjek yang memenuhi kriteria penelitian sebagai peserta, guna melihat apakah hasil transadaptasi dan modifikasi skala yang telah dilakukan dapat dipahami dengan baik oleh calon subjek penelitian. Proses FGD menghasilkan masukan berupa 
beberapa review mengenai preferensi cara pengisian dan tampilan skala, lokasi dan kegiatan yang digambarkan dalam skala (yang dianggap masih cukup asing bagi peserta FGD) serta penambahan konten untuk mempermudah subjek membayangkan lokasi atau kegiatan yang dimaksudkan dalam skala penelitian.

\begin{abstract}
Alat Ukur
Big Five Inventory 44-item Scale merupakan skala yang dikembangkan oleh John O.P \& Srivastava (1990) dengan skala awal oleh Goldberg (1981) yang kemudian telah ditrans-adaptasi oleh Ramdhani (Ramdhani, 2012). Penelitian ini menggunakan skala Likert 4 poin (Cronbach's $\alpha=.615$ ), dengan I menunjukkan Sangat Tidak, 2 tidak setuju, 3 Setuju dan 4 menunjukkan Sangat Setuju. . Terdiri dari 44 aitem yang dikelompokan kedalam lima subskala. Skor tinggi menunjukkan bahwa responden memiliki kecenderungan terhadap subskala tersebut, sedangkan skor rendah menunjukkan kebalikannya. Lalu skala kedua adalah Hard Adventure type (Scott \& Mowen, 2007) yang sebelumnya telah dilakukan proses transadaptasi dengan acuan Beaton (2000), modifikasi, dan Focus Group Discussion (FGD), terdiri dari 6 aitem. Masing-masing aitem bernilai 4 poin skala Likert, mulai dari I untuk Sangat Tidak Setuju hingga interval 4 untuk Sangat Setuju. Skala ini mengukur kecenderungan individu terhadap tipe perjalanan Hard Adventure, dengan nilai Cronbach's $\alpha$ skala sama dengan 0,8I4. Skala penelitian disebarkan secara online kepada warga negara Indonesia yang memenuhi kriteria subjek penelitian melalui media sosial. Metode penyebaran yakni membagikan dengan cara diunggah melalui media sosial sehingga subjek hanya perlu mengisi skala penelitian dengan membuka tautan yang telah disediakan.
\end{abstract}

Terdapat lebih banyak responden berjenis kelamin perempuan yang berkontribusi dalam penelitian ini, yaitu sebesar $84 \%$. Dominasi jumlah jumlah tersebut sejalan dengan penelitian yang dilakukan oleh Tilley \& Houston (2016) dimana seiring bertambahnya usia, wanita lebih sering berpergian atau travelling dibandingkan dengan laki-laki. Peneliti menggunakan rentang usia yang juga digunakan oleh Kementrian Pariwisata Indonesia untuk membantu kategorisasi kelompok usia responden. Responden pada penelitian ini didominasi oleh traveller pada kelompok usia 18 - 24. Hal tersebut terjadi dikarenakan menurut laporan dari Canadian Tourism Commission (2015) Generasi milenium atau individu yang lahir di tahun 80an dan 90an, bepergian lebih sering dan lebih jauh daripada kelompok usia lainnya. UNWTO (2010) pun memperkirakan bahwa sekitar $20 \%$ dari 940 juta wisatawan internasional yang melakukan perjalanan dunia adalah kaum muda. Seperti yang disampaikan oleh Hermawan \& Hendrastomo (2017) bahwa saat ini travelling telah menjadi gaya hidup mahasiswa, dimana kegiatan tersebut dilakukan untuk mengisi waktu luang yang ada disela-sela rutinitas perkuliahan. Mosonyi, Könyves, Fodor, \& Müller (2013) dalam penelitian mengenai kegiatan rekreasi dan kebiasaan travelling pada mahasiswa menemukan bahwa 92\% dari mahasiswa melakukan travelling setidaknya setahun sekali. Sehingga tidak mengherankan apabila responden yang paling banyak berkontribusi dalam penelitian ini merupakan pelajar/mahasiswa dengan prosentase sebesar 61.2\%. Mayoritas responden dari penelitian ini merupakan pelajar/mahasiswa yang pada umumnya masih menjadi pekerja paruh waktu atau bahkan belum memiliki pendapatan dan masih bergantung pada uang saku yang diberikan orangtua, sehingga mayoritas subjek pada penelitian ini berada pada kelompok pendapatan dibawah Rp.500.000,-.

\title{
Deskripsi subjek berdasarkan gambaran diri dalam melakukan travelling
}

Responden dalam penelitian ini didominasi oleh subjek yang memilih untuk melakukan travelling bersama dengan kelompok dibandingkan melakukan travelling sendiri atau opentrip. Seperti pada Holiday Habit Report yang dilakukan oleh ABTA pada tahun 20I8, diketahui bahwa $51 \%$ traveller lebih menyukai bepergian bersama dengan pasangan, 33\% memilih untuk travelling bersama dengan keluarga dekat dan $4 \%$ traveller memilih untuk bepergian dengan rekan atau teman. Hal ini dapat dijelaskan dengan survei yang dilakukan oleh CWT (2017), alasan individu cenderung berpergian dengan kelompok dikarenakan saat ini generasi millenial memiliki karakteristik senang untuk berinteraksi dengan orang lain ketika melakukan travelling dibandingkan generasi sebelumnya. 
Deskripsi subjek berdasarkan gambaran diri dalam merencanakan travelling

Responden pada penelitian ini didominasi oleh subjek yang lebih memilih untuk merencanakan travelling secara mandiri, yaitu sebanyak 1427 subjek atau sebesar $91.6 \%$ dari total responden, dibanding yang memilih untuk menggunakan jasa agensi travel yang hanya sebesar $8.4 \%$. Hal ini dikarenakan nilai flexibilitas yang akan didapatkan ketika merencanakan sendiri perjalanan sesuai yang diinginkan traveler. Saat ini merencanakan secara mandiri perjalanan yang akan dilakukan juga didukung dengan adanya kemudahan dalam mengakses internet yang menyediakan informasi untuk mempresentasikan secara visual berbagai destinasi wisata yang mungkin tidak seluruhnya dapat dijangkau oleh agensi travel (Bhati, Hoong, Chang, Fong, \& Kaur, 2013).

Tabel I

Deskripsi data subyek

\begin{tabular}{|c|c|c|}
\hline \multicolumn{3}{|l|}{ Jenis Kelamin Subjek } \\
\hline Kategori & Jumlah & Prosentase \\
\hline Laki-laki & & $16 \%$ \\
\hline Perempuan & & $84 \%$ \\
\hline \multicolumn{3}{|l|}{ Usia } \\
\hline Rentang Usia & Jumlah & Prosentase \\
\hline $18-24$ & 1277 & $81.96 \%$ \\
\hline $25-34$ & 212 & $13.61 \%$ \\
\hline $35-44$ & 57 & $3.66 \%$ \\
\hline $45-54$ & 12 & $0.77 \%$ \\
\hline \multicolumn{3}{|l|}{ Pekerjaan Subjek } \\
\hline Jenis Pekerjaan & Jumlah & Prosentase \\
\hline Pelajar/Mahasiswa & 978 & $61.2 \%$ \\
\hline Pegawai Negeri & 23 & $1.4 \%$ \\
\hline Pegawai Swasta & 381 & $23.9 \%$ \\
\hline Wirausaha & 95 & $5.9 \%$ \\
\hline Ibu/Bapak Rumah Tangga & 39 & $2.4 \%$ \\
\hline Lainnya & 42 & $5.2 \%$ \\
\hline \multicolumn{3}{|l|}{ Pendapatan Subjek } \\
\hline Jumlah Pendapatan & Jumlah & Prosentase \\
\hline$<$ Rp. 500.000 & 495 & $31.8 \%$ \\
\hline Rp. $500.000-$ Rp. 1.000 .000 & 251 & $16.1 \%$ \\
\hline Rp. I.000.00I - Rp. 2.000 .000 & 307 & $19.7 \%$ \\
\hline Rp. 2.000 .001 - Rp. 3.000 .000 & 158 & $10.1 \%$ \\
\hline Rp. 3.000 .001 - Rp. 5.000 .000 & 218 & $14 \%$ \\
\hline \multicolumn{3}{|c|}{ Gambaran diri dalam melakukan travelling } \\
\hline Gambaran Travelling & llah & Prosentase \\
\hline Travelling Sendiri & 229 & $14.7 \%$ \\
\hline Travelling Kelompok & 1226 & $78.7 \%$ \\
\hline Open Trip & 103 & $6.6 \%$ \\
\hline
\end{tabular}

\section{Hasil}

Kecenderungan openness pada subjek dalam penelitian ini paling banyak berada pada kategorisasi sedang yaitu sejumlah 964 subjek. Begitu juga dengan kecenderungan conscientiousness, extraversion dan neuroticism yang masing-masing berjumlah 837, 984 dan 1066 subjek. Sementara kecenderungan agreeableness dan kecenderungan tipe travelling softadventure dalam penelitian ini didominasi oleh responden dengan kategorisasi tinggi yang berjumlah I 294 dan 1528 subjek. 
Tabel 2

Deskripsi Kategorisasi data penelitian

\begin{tabular}{|c|c|c|c|}
\hline Variabel & $\begin{array}{l}\text { Nilai Daerah } \\
\text { Keputusan }\end{array}$ & Kategorisasi & $\begin{array}{l}\text { Jumlah } \\
\text { Subjek \% }\end{array}$ \\
\hline & $x<20$ & Rendah & $0.32 \%$ \\
\hline \multirow[t]{3}{*}{ Openness } & $20 \leq X 30$ & Sedang & $61.1 \%$ \\
\hline & $30 \leq X$ & Tinggi & $38.5 \%$ \\
\hline & $x<18$ & Rendah & $0.96 \%$ \\
\hline \multirow[t]{3}{*}{ Conscientiousness } & $18 \leq \times 27$ & Sedang & $53.7 \%$ \\
\hline & $27 \leq X$ & Tinggi & $45.3 \%$ \\
\hline & $x<16$ & Rendah & $0.12 \%$ \\
\hline \multirow[t]{3}{*}{ Extraversion } & $16 \leq \times 24$ & Sedang & $61.8 \%$ \\
\hline & $24 \leq X$ & Tinggi & $37.9 \%$ \\
\hline & $x<18$ & Rendah & $0.06 \%$ \\
\hline \multirow[t]{3}{*}{ Agreeableness } & $18 \leq \times 27$ & Sedang & $16.8 \%$ \\
\hline & $27 \leq X$ & Tinggi & $83 \%$ \\
\hline & $x<16$ & Rendah & $14.3 \%$ \\
\hline \multirow[t]{3}{*}{ Neuroticism } & $16 \leq \times 24$ & Sedang & $68.4 \%$ \\
\hline & $24 \leq x$ & Tinggi & $17.2 \%$ \\
\hline & $x<10$ & Rendah & $0.06 \%$ \\
\hline \multirow[t]{2}{*}{ Soft-adventure travel } & $10 \leq \times 15$ & Sedang & $1.86 \%$ \\
\hline & $15 \leq x$ & Tinggi & $98 \%$ \\
\hline
\end{tabular}

Setelah semua variabel dipastikan lolos uji asumsi, peneliti melakukan beberapa analisis untuk menguji hipotesis penelitian yang telah ditetapkan. Analisis tersebut antara lain meliputi analisis multiple linear regression antara big-five personality dengan psychological well-being, kemudian analisis multiple linear regression antara traveling types dengan psychological well being, selanjutnya analisis multiple linear regression antara big-five personality dengan soft traveling type, dilanjutkan dengan analisis multiple linear regression big-five personality dengan hard traveling type, diteruskan dengan analisis multiple linear regression big-five personality dengan luxury traveling type, dan analisis yang terakhir adalah analisis multiple linear regression antara big-five personality dengan camping traveling type.

Tabel 6 menunjukkan bahwa trait kepribadian conscientiousness, extraversion, openness to experience, dan agreeableness memiliki peran positif terhadap psychological well-being, sedangkan trait kepribadian neuroticism memiliki peran negatif terhadap psychological well-being. Secara simultan big-five personality menggambarkan $50.5 \%$ variance dari psychological well-being.

Tabel 3

Multiple Linear Regression Big-Five Personality dan Psychological Well-Being

\begin{tabular}{lccc}
\hline & \multicolumn{3}{c}{ Psychological Well-Being } \\
\hline Independent Variables & $\boldsymbol{6}$ & t-value & $\boldsymbol{\rho}$ \\
\hline Openness to Experience & $0.163^{* *}$ & 8.458 & 0.000 \\
Conscientiousness & $0.313^{* *}$ & 14.378 & 0.000 \\
Extraversion & $0.080^{* *}$ & 4.117 & 0.000 \\
Agreeableness & $0.237^{* *}$ & 11.426 & 0.000 \\
Neuroticism & $-0.240^{* *}$ & -11.227 & 0.000 \\
$\mathrm{R}^{2}$ & 0.505 & \multicolumn{3}{c}{} \\
\hline \multicolumn{4}{c}{ Psychological Well-Being } \\
\hline Independent Variables & \multicolumn{6}{c}{$\boldsymbol{t}$-value } & $\boldsymbol{\rho}$ \\
\hline Soft Travel & $0.220^{* *}$ & 8.535 & 0.000 \\
Hard Travel & 0.009 & 0.317 & 0.752 \\
Luxury Travel & -0.029 & -1.196 & 0.232 \\
Camping & $0.147^{* *}$ & 5.009 & 0.000 \\
$\mathrm{R}^{2}$ & 0.096 & & \\
\hline
\end{tabular}


${ }^{*} \mathrm{p}<0.05 ; * * \mathrm{p}<0.01$

Tabel 3 menunjukkan bahwa soft traveling type dan camping traveling type memiliki peran positif terhadap psychological well-being, sedangkan hard traveling type dan luxury traveling type tidak memiliki peran signifikan terhadap psychological well-being. Secara simultan traveling type menggambarkan $9 \%$ variance psychological well-being.

Tabel 4

Multiple Linear Regression Big-Five Personality dan Traveling Type

\begin{tabular}{|c|c|c|c|}
\hline \multirow[b]{2}{*}{ Independent Variables } & \multicolumn{3}{|c|}{ Soft Traveling Type } \\
\hline & b & t-value & $\rho$ \\
\hline Openness to Experience & -0.009 & -0.358 & 0.721 \\
\hline Conscientiousness & $0.114 * *$ & 3.911 & 0.000 \\
\hline Extraversion & $0.149 * *$ & 5.734 & 0.000 \\
\hline Agreeableness & $0.207^{* *}$ & 7.462 & 0.000 \\
\hline Neuroticism & 0.014 & 0.483 & 0.629 \\
\hline \multirow[t]{2}{*}{$\mathrm{R}^{2}$} & 0.114 & & \\
\hline & \multicolumn{3}{|c|}{ Hard Traveling Type } \\
\hline Independent Variables & B & t-value & $\rho$ \\
\hline Openness to Experience & $0.140 * *$ & 5.319 & 0.000 \\
\hline Conscientiousness & -0.057 & -1.919 & 0.055 \\
\hline Extraversion & $0.124 * *$ & 4.697 & 0.000 \\
\hline Agreeableness & 0.013 & 0.445 & 0.657 \\
\hline Neuroticism & $-0.173 * *$ & -5.916 & 0.000 \\
\hline \multirow[t]{2}{*}{$\mathrm{R}^{2}$} & 0.076 & & \\
\hline & \multicolumn{3}{|c|}{ Luxury Traveling Type } \\
\hline Independent Variables & B & t-value & $\rho$ \\
\hline Openness to Experience & 0.045 & 1.655 & 0.098 \\
\hline Conscientiousness & $0.063^{*}$ & 2.082 & 0.037 \\
\hline Extraversion & 0.035 & 1.293 & 0.196 \\
\hline Agreeableness & -0.013 & -0.446 & 0.656 \\
\hline Neuroticism & $0.181 * *$ & 6.053 & 0.000 \\
\hline \multirow[t]{2}{*}{$\mathrm{R}^{2}$} & 0.029 & & \\
\hline & \multicolumn{3}{|c|}{ Camping Traveling Type } \\
\hline Independent Variables & 6 & t-value & $\rho$ \\
\hline Openness to Experience & $0.154 * *$ & 5.934 & 0.000 \\
\hline Conscientiousness & $-0.084 * *$ & -2.869 & 0.004 \\
\hline Extraversion & $0.179 * *$ & 6.836 & 0.000 \\
\hline Agreeableness & $0.107 * *$ & 3.842 & 0.000 \\
\hline Neuroticism & $-0.085^{* *}$ & $-2.94 I$ & 0.003 \\
\hline $\mathrm{R}^{2}$ & 0.100 & & \\
\hline
\end{tabular}

Tabel 4 menunjukkan bahwa trait kepribadian conscientiousness, extraversion, dan agreeableness memiliki peran positif terhadap soft traveling type, sedangkan trait kepribadian neuroticism dan openness to experience tidak memiliki peran yang signifikan terhadap soft traveling type. Secara simultan big-five personality menggambarkan II.4\% variance dari soft traveling type. 
Selain itu trait kepribadian extraversion dan openness to experience memiliki peran positif terhadap hard traveling type, trait kepribadian neuroticism memiliki peran negatif terhadap hard traveling type, sedangkan trait kepribadian conscientiousness dan trait kepribadian agreeableness tidak memiliki peran yang signifikan terhadap hard traveling type. Secara simultan big-five personality menggambarkan $7.6 \%$ variance dari hard traveling type.

Tabel 4 menunjukkan bahwa trait kepribadian neuroticism dan conscientiousness memiliki peran positif terhadap luxury traveling type, sedangkan trait kepribadian openness to experience, extraversion, dan agreeableness tidak memiliki peran yang signifikan terhadap luxury traveling type. Secara simultan big-five personality menggambarkan $2.9 \%$ variance dari luxury traveling type.

Tabel 4 menunjukkan bahwa trait kepribadian extraversion dan openness to experience, dan agreeableness memiliki peran positif terhadap camping traveling type, sedangkan trait kepribadian neuroticism dan conscientiousness memiliki peran negatif terhadap camping traveling type. Secara simultan big-five personality menggambarkan 10\% variance dari camping traveling type.

\section{Pembahasan}

Untuk psychological well-being, seluruh trait kepribadian yang terdapat di dalam big-five personality yaitu conscientiousness, neuroticism, openness to experience, extraversion, dan agreeableness memiliki peran masing-masing dalam meningkatkan kesejahteraan psikologis. Temuan tersebut menandakan bahwa setiap individu dengan trait apapun memiliki peluang untuk mendapatkan kesejahteraan psikologis. Jika dilihat dari sudut pandang tipe traveling yang terdiri dari soft traveling type, hard traveling type, luxury traveling type, dan camping traveling type, hanya terdapat dua tipe yang memiliki peran positif terhadap kesejahteraan psikologis yaitu soft traveling type dan camping traveling type. Soft traveling type adalah kegiatan travelling yang dilakukan di tempat yang nyaman dengan resiko rendah yang menekankan pada kegiatan yang dilakukan secara bersama-sama dengan orang lain, sedangkan camping traveling type merupakan kegiatan travelling yang dilakukan di tempat terbuka dengan fokus berupa pengalaman dan interaksi individu dengan alam bebas. Hard traveling type tidak memiliki peran dalam kesejahteraan psikologis karena mengandung resiko yang sangat tinggi, sedangkan luxury traveling type tidak memiliki peran terhadap kesejahteraan psikologis karena adanya faktor yang lebih berperan yaitu kemampuan finansial yang sangat penting untuk melakukan tipe traveling luxury yang penuh dengan unsur kemewahan.

Untuk soft traveling type, trait pertama yang berperan adalah trait kepribadian conscientiousness (C), dimana trait $C$ berkorelasi positif terhadap kecenderungan tipe travelling soft-adventure yang mengartikan bahwa semakin besar kecenderungan $C$ maka semakin besar pula kecenderungan individu dalam memilih tipe travelling soft-adventure. Hal ini dikuatkan dengan facet-facet kecenderungan kepribadian $\mathrm{C}$, yaitu individu dengan kecenderungan kepribadian $\mathrm{C}$ digambarkan sebagai individu yang terkontrol, penuh pertimbangan dan berhati-hati (McCrae \& Costa, 2003) sehingga sesuai dengan karakteristik tipe travelling soft-adventure yang memiliki tingkat resiko rendah, memiliki hasil yang pasti, dapat diatur secara detail, dan berada lokasi di lingkungan yang aman dan terkendali (Scott \& Mowen, 2007; Swarbrooke et al., 2003). Penjabaran tersebut sejalan dengan penelitian Jani (2014) yang menghubungkan BFP dengan travel personality, dimana terdapat hasil bahwa individu dengan kecenderungan $C$ tinggi menyukai kegiatan travelling keluarga yang aman dan nyaman dengan resiko yang sangat rendah.

Trait kepribadian selanjutnya yang memiliki peran terhadap tipe travelling soft-adventure adalah trait extraversion (E) yang memiliki korelasi bernilai positif, hal tersebut menjelaskan bahwa semakin besar kecenderungan $E$ seseorang maka semakin besar pula kecenderungan mereka memilih tipe travelling soft-adventure. Individu dengan kecenderungan kepribadian E digambarkan sebagai individu yang menikmati serta menyukai hubungan dengan banyak orang, penuh semangat dan senang berpetualang (McCrae \& Costa, dalam Cervone \& Pervin, 2012) dimana hal tersebut selaras dengan kecenderungan soft-adventure travel yang sering menjadi bagian dari perjalanan kelompok dan merupakan kegiatan dengan kesempatan untuk bersosialisasi dalam lingkungan yang terkendali (Scott \& Mowen, 2007; Swarbrooke et al., 2003). Penjelasan tersebut didukung dengan penelitian mengenai efek BFP terhadap tipe rekreasi oleh Tran, Nguyen \& Nguyen (2015) yang menemukan 
hubungan signifikan antara trait kepribadian E dengan interaksi sosial, termasuk melakukan perjalanan jauh, berinteraksi, bersosialisasi dan berkumpul dengan wisatawan lain.

Trait kepribadian yang juga memiliki korelasi positif dengan kecenderungan tipe travelling softadventure adalah trait agreeableness (A). Sama seperti trait sebelumnya hal ini menjelaskan bahwa semakin besar kecenderungan trait kepribadian $A$ individu semakin besar juga kecenderungan individu dalam memilih tipe travelling soft-adventure. Ini sejalan dengan facet dari kepribadian A yang digambarkan dengan individu yang memiliki intimacy dan altruisme tinggi, compliance serta selalu berusaha menghindari konflik (John \& Srivastava, 1999 dalam Wulandari \& Rehulina, 2013). Hal tersebut cocok dengan tipe travelling soft-adventure yang sering menjadi bagian perjalanan kelompok, terdiri dari kegiatan-kegiatan santai yang aman dan jauh dari melanggar nilai ataupun norma yang ada, serta menawarkan kenyamanan yang lebih besar untuk individu memperoleh kualitas berkumpul dengan kelompoknya (Scott \& Mowen, 2007; Swarbrooke et al., 2003). Hasil yang diperoleh selaras dengan penelitian yang dilakukan Scott dan Mowen (2007) yang mendapatkan hasil serupa pada traveller Amerika. Penjabaran tersebut juga didukung dengan penemuan Fluker dan Turner (2000) yang menyatakan bahwa motivasi untuk terlibat dalam adventure travel adalah untuk menikmati kebersamaan dalam kelompok.

Untuk hard traveling type, trait openness menunjukan korelasi positif dengan nilai tertinggi yang dapat disimpulkan bahwa semakin tinggi individu memiliki kecenderungan trait openness, maka kecenderungan individu tersebut terhadap tipe perjalanan hard adventure juga akan semakin tinggi. Hasil ini sesuai dengan karakteristik yang dimiliki oleh trait openness, bahwa trait ini menggambarkan bagaimana minat seseorang terhadap pengalaman yang baru. Individu dengan tingkat openness yang tinggi cenderung menyukai hal-hal baru. Individu yang terbuka pada pengalaman cenderung mencari perbedaan dan pengalaman yang bervariasi dan berbeda (Feist \& Feist, 2009). Facet yang menggambarkan trait openness juga memperkuat hasil dalam penelitian ini, seperti penuh rasa ingin tahu, memiliki minat yang beragam, dan penuh semangat. Ketika melakukan perjalanan wisata pun individu dengan trait ini cenderung akan menyukai tipe hard adventure karena, semakin tinggi tantangan dan resiko yang dimiliki akan semakin membuat individu tersebut berkeinginan untuk melakukannya. Hill (Schott, 2007) mengatakan bahwa dalam melakukan wisata yang termasuk ke dalam hard adventure dibutuhkan keterampilan dalam menghadapi situasi yang berbahaya. Lokasi dan kegiatan beresiko tersebut akan memenuhi kebutuhan individu dengan trait openness karena mereka semakin tertantang dan ingin mengetahui rasanya melakukan kegiatan tersebut.

Kemudian, trait kedua yang juga memiliki korelasi yang positif terhadap hard adventure adalah extraversion. Individu dengan trait ini menunjukkan tingkat kesenangan terhadap suatu hubungan dengan orang lain. Individu dengan tingkat extraversion yang tinggi memiliki ciri cenderung ramah, terbuka dan menghabiskan banyak waktu untuk mempertahankan dan menikmati hubungan dengan orang lain. Ciri lain yang dimiliki oleh individu dengan tingkat extraversion yang tinggi adalah aktif berbicara, mudah bergaul dengan orang lain, menyenangkan, dan menyukai berhubungan dengan banyak orang (Feist \& Feist, 2009). Ketika melakukan kegiatan yang penuh resiko seseorang cenderung akan saling membantu karena kondisi tersebut, sehingga individu dengan trait ini tidak akan mengalami kesusahan berkomunikasi saat melakukan kegiatan-kegiatan tersebut.

Trait neuroticism juga memiliki korelasi terhadap tipe hard adventure, namun korelasi tersebut merupakan korelasi negatif. Hasil menunjukkan bahwa trait ini memiliki korelasi negatif yang tinggi terhadap hard adventure, individu dengan trait neuroticism akan menghindari melakukan kegiatan yang terdapat dalam tipe ini karena banyaknya resiko-resiko yang dapat terjadi ketika melakukan kegiatan pada tipe ini. Orang yang memiliki trait neuroticism yang tinggi akan cenderung merasa cemas dan rentan untuk terkena gangguan stres (Feist \& Feist, 2009). Hasil pada penelitian ini juga semakin diperkuat dengan facet yang menggambarkan trait neuroticism, menurut John \& Srivastava facet dari trait neuroticism yaitu cemas, memiliki kecenderungan depresi, pemalu, dan kurang percaya diri (Wulandari \& Rehulina, 20I3). Oleh sebab itu dapat diartikan bahwa, semakin rendah individu dengan trait neuroticism maka keinginan untuk melakukan kegiatan pada tipe hard adventure akan semakin tinggi. 
Untuk luxury traveling type, peran dari trait neuroticism terhadap kecenderungan luxury-travel berkorelasi secara positif, sehingga dapat diartikan semakin tingginya tingkat kecenderungan neuroticism individu maka semakin besar pula kecenderungan individu tersebut memilih luxurytravel. Hal ini selaras dengan salah satu karakteristik dari trait neuroticism yaitu mudahnya merasa cemas dan kurang percaya diri (McCrae \& Costa, 2003) dimana dari hal tersebut individu akan mencari kepastian dan ketenangan akan suatu hal dalam menghadapi kecemasan yang dialami. Begitu pula dengan facet kurangnya percaya diri yang dimiliki sehingga individu dengan neuroticism tinggi akan cenderung mencari pengakuan sosial atau prestise dari apa yang akan ia lakukan (Boeree, 2006). Sehingga luxury-travel yang memiliki karakteristik perjalanan identik dengan lokasi maupun fasilitas yang prestisius serta aman dan nyaman yang terjamin (Amadeus, 2016) akan memenuhi kebutuhan dari individu yang memiliki kecenderungan neuroticism tinggi. Tran (2015) dalam penelitian yang dilakukannya mengatakan bahwa trait neuroticism kuat kaitannya dengan aktivitas bargaining atau tawar menawar sehingga destinasi seperti tempat kasino akan tepat untuk individu dengan kecenderungan neuroticism, dimana kasino sendiri merupakan tempat yang penuh dengan kemewahan.

Kemudian trait conscientiousness sebagai trait kedua yang memiliki peran yang signifikan terhadap kecenderungan tipe luxury-travel. Memiliki nilai korelasi yang positif menunjukan bahwa semakin tinggi tingkat kecenderungan conscientiousness yang dimiliki individu maka semakin tinggi pula kecenderungan individu tersebut untuk memilih perjalanan dengan tipe luxury-travel. Hal tersebut selaras dengan karakteristik dari trait conscientiousness yakni memiliki kesadaran penuh akan apa yang sedang dilakukan, terencana, hati-hati, tepat waktu, dan gigih (McCrae \& Costa, 2003), dimana hal tersebut akan terpenuhi oleh karakteristik utama dari luxury-travel yaitu keamanan serta kenyamanan dari segala fasilitas yang terjamin keadaannya.

Perjalanan dengan tipe luxury-travel identik dengan adanya kepercayaan konsumen pada peran agensi travel yang memiliki kapabilitas khusus untuk menyediakan sebuah perjalanan mewah (AmadeusTravel, 2016), sehingga konsumer tidak lagi perlu repot memikirkan dan merencanakan rincian detail perjalanan ini memenuhi kebutuhan dari kenyamanan dan kepastian yang dibutuhkan trait conscientiousness. Lalu dengan adanya sebuah value yang dijunjung tinggi dalam luxury-travel yakni pengetahuan, keterampilan, dan keahlian yang piawai (Brown \& Hudson, 20II), sehingga selaras dengan hasil dari penelitian oleh Tran (2015) yang menyatakan bahwa trait conscientiousness memiliki keterkaitan terhadap ilmu pengetahuan (knowledge), maka sebuah petualangan eksklusif seperti perjalanan ke kutub utara atau perjalanan keluar angkasa (Swarbrooke, Beard, Leckie, \& Pomfret, 2003) merupakan perjalanan yang cocok, dikarenakan conscientiousness memiliki ambisi yang tinggi untuk berkembang juga sebagai salah satu facet-nya.

Untuk camping traveling type, trait extraversion (E) berada pada peringkat pertama trait yang memiliki peran positif terhadap kecenderungan camping travel, sehingga dapat diartikan bahwa semakin tinggi kecenderungan trait $E$ seseorang, maka semakin besar kemungkinan ia memilih tipe camping travel dalam kegiatan travelingnya. Hasil penelitian terhadap trait $\mathrm{E}$ ini bisa dikaitkan dengan gambaran facet extraversion yang menurut McCrae dan Costa (2003) adalah hangat, memiliki kemampuan sosialisasi yang baik, dan menyukai petualangan. Laporan dari FSUSDA (1967) menyebutkan bahwa para camper adalah orang-orang yang mudah bergaul dan menikmati interaksi dengan orang lain, bahkan interaksi dengan camper lain menjadi salah satu alasan utama mereka melakukan kegiatan camping. Temuan FSUSDA tersebut memperkuat hasil penelitian ini yang menunjukkan adanya peran positif trait $E$ terhadap kecenderungan camping travel.

Trait openness $(\mathrm{O})$ menjadi trait kedua yang memiliki peran positif terhadap kecenderungan camping travel seseorang. Orang-orang yang memiliki kecenderungan tinggi pada trait $O$ yang tinggi akan semakin cenderung memilih kegiatan dengan jenis camping travel. Hasil penelitian ini sesuai dengan facet trait $O$ yang digambarkan oleh McCrae dan Costa (2003) sebagai orang-orang yang cenderung imajinatif, menyukai pengalaman baru, dan memiliki minat yang beragam. Kegiatan camping memiliki banyak kemungkinan yang bisa terjadi di luar dugaan, seperti cuaca dan kondisi medan camping yang berubah, hingga berbagai macam camper lain yang mungkin ditemui selama kegiatan camping. Hal-hal tersebut dapat menunjang kebutuhan trait $\mathrm{O}$ yang menyukai pengalaman baru. Temuan ini sejalan dengan penelitian Mcfarlane, dkk (2003) yang menyatakan bahwa salah 
satu alasan masyarakat melakukan kegiatan camping adalah untuk merasakan kebebasan di alam terbuka, beristirahat dari kegiatan rutin, mencoba pengalaman baru.

Trait agreeableness (A) adalah trait ketiga yang memiliki hubungan positif dengan kecenderungan camping travel. Orang-orang dengan trait A yang tinggi cenderung akan memilih kegiatan yang tergolong sebagai camping travel. Hal ini sesuai dengan facet trait A yang digambarkan sebagai orang-orang yang mudah diajak bekerja sama, ramah, tidak banyak menuntut dan sederhana. FSUSDA (1967) menyebutkan bahwa lokasi camping biasanya hanya menyediakan fasilitas yang sederhana bagi para camper, seperti api unggun, jamban, dan tempat memasak sederhana guna memaksimalkan pengalaman interaksi dengan alam para camper. $\mathrm{Hal}$ ini memperkuat peran positif trait A terhadap kecenderungan camping travel seseorang yang memiliki kesederhanaan tinggi dan tidak banyak menuntut. Interaksi dengan camper lain juga menuntut kemampuan kerjasama yang baik dan hal tersebut dimiliki oleh individu dengan tingkat agreeableness tinggi.

Trait conscientiousness (C) memiliki hubungan negatif dengan kecenderungan camping travel seseorang. Hal ini dapat diartikan sebagai semakin rendah kecenderungan trait $\mathrm{C}$ seseorang, maka semakin ia akan memilih kegiatan yang termasuk dalam jenis camping travel. Hal ini sesuai dengan penelitian Scott dan Mowen (2007) yang juga menemukan adanya hubungan dengan signifikansi yang negatif diantara keduanya. Orang-orang dengan kecenderungan trait $C$ yang rendah digambarkan sebagai orang yang tidak memiliki tujuan spesifik dan tidak menyukai terikat dengan aturan dan rencana. Gambaran ini sesuai dengan kondisi camping travel dimana dengan berbagai kemungkinan yang bisa terjadi, rencana yang telah disusun oleh para camper bisa berubah setiap saat. Berkaca dari hasil temuan McFarlane, dkk (2003) yang menyebutkan diantara alasan masyarakat memilih tipe camping travel adalah untuk menikmati kebebasan dan tidak adanya aturan tertentu, dan untuk menikmati alam dan melatih kemampuan outdoor.

Trait neuroticism $(\mathrm{N})$ adalah trait kedua yang memiliki hubungan negatif dengan kecenderungan camping travel, sehingga semakin rendah tingkat neuroticism seseorang maka akan semakin akan memilih camping travel. Hasil ini sesuai dengan penggambaran mengenai orang-orang dengan tingkat trait $\mathrm{N}$ rendah, yaitu tenang, santai, dan tidak emosional (McCrae \& Costa, 2003). Hal ini sejalan dengan hasil penelitian McFarlane, dkk (2003) yang menyebutkan bahwa alasan orang-orang melakukan kegiatan camping adalah untuk bersantai, mencari ketenangan dan menikmati alam. Kegiatan camping yang memiliki banyak kemungkinan selama pelaksanaannya juga membutuhkan karakter individu yang mampu mengendalikan emosinya dengan baik yang juga dimiliki oleh individu dengan tingkat trait $\mathrm{N}$ yang rendah.

\section{Kesimpulan}

Trait terbukti memiliki peran pada psychological wellbeing traveller. Conscientiousness, extraversion, openness to experience, dan agreeableness memiliki peran positif terhadap psychological well-being, sedangkan neuroticism memiliki peran negatif terhadap psychological well-being. Secara simultan big-five personality menggambarkan $50.5 \%$ variance dari psychological well-being. Sedangan berdasarkan tipe travelling, penelitian ini menunjukan beberapa kesimpulan yang berbeda pada peran tipe travelling terhadap psychological wellbeing. Soft traveling type dan camping traveling type memiliki peran positif terhadap psychological well-being, sedangkan hard traveling type dan luxury traveling type tidak memiliki peran signifikan terhadap psychological wellbeing. Secara simultan traveling type menggambarkan $9 \%$ variance psychological well-being.

Penelitian ini memiliki kesimpulan peran antara trait personality terhadap tipe travelling. Conscientiousness, extraversion, dan agreeableness memiliki peran positif terhadap soft traveling type, sedangkan neuroticism dan openness to experience tidak memiliki peran yang signifikan terhadap soft traveling type. Secara simultan big-five personality menggambarkan $11.4 \%$ variance dari soft traveling type. Extraversion dan openness to experience memiliki peran positif terhadap hard traveling type, neuroticism memiliki peran negatif terhadap hard traveling type, sedangkan conscientiousness dan agreeableness tidak memiliki peran yang signifikan terhadap hard traveling type. Secara simultan big-five personality menggambarkan $7.6 \%$ variance dari hard traveling type. Neuroticism dan conscientiousness memiliki peran positif terhadap luxury traveling type, 
sedangkan openness to experience, extraversion, dan agreeableness tidak memiliki peran yang signifikan terhadap luxury traveling type. Secara simultan big-five personality menggambarkan $2.9 \%$ variance dari luxury traveling type.Extraversion dan openness to experience, dan agreeableness memiliki peran positif terhadap camping traveling type, sedangkan neuroticism dan conscientiousness memiliki peran negatif terhadap camping traveling type. Secara simultan big-five personality menggambarkan $10 \%$ variance dari camping traveling type.

Berdasarkan kesimpulan yang sudah dikemukakan, peneliti memiliki beberapa saran yang diharapkan bisa dilakukan untuk masa yang akan datang. Potensi peningkatan ekonomi dapat dilihat dari peningkatan traveler ke sejumlah destinasi, hal ini harus diimbangi dengan pemahaman pelaku wisata bahwa terdapat tipe traveling dan tipe kepribadian traveller yang harus difasilitasi di dalam destinasi wisata. Hasil penelitian dapat dijadikan sebagai pertimbangan dalam membuat kebijakan terkait dengan pengembangan pariwisata di Indonesia dan dapat dijadikan sebagai pertimbangan terkait dengan strategi marketing dalam rangka meningkatkan pengunjung tempat wisata dan promosi baik nasional maupun internasional khususnya dari sudut pandang trait kepribadian para pengujung yang disesuaikan dengan jenis tempat wisata.

\section{REFERENSI}

Abbate, C. S., \& Di Nuovo, S. (2013). Motivation and personality traits for choosing religious tourism. A research on the case of Medjugorge. Current issues in tourism, I6(5), 50I-506.

ABTA. (20I8). Holiday habits report 20/8. Retrieved from https//www.abta.com/industryzone/reports-and-publications/abta-holiday-habits-reports/holiday-habits-report-2018

Allik, J., \& McCrae, R. R. (2004). Toward a geography of personality traits: Patterns of profiles across 36 culture. Journal of Cross-Cultural Psychology, 35, I3-28.

Azwar, S. (2012). Metode penelitian. Yogyakarta: Pustaka Pelajar.

Badan Pusat Statistik Kemenetrian Pariwisata. (2018). Kajian data pasar wisatawan nusantara. Jakarta. Retrieved from http://www.kemenpar.go.id/userfiles/Publikasi Kajian Data Pasar Wisnus 2017.pdf

Barrick, M. R., \& Ryan, A. M. (2003). Personality and work: Reconsidering the role of personality in organization. San Farnsisco: Jossey-Bas.

Bhati, A. S., Hoong, C. T., Chang, J., Fong, L., \& Kaur, K. (20I3). Personalised travel services : An exploratory study in singapore context. Journal of business review, $3(\mathrm{I})$. https://doi.org//0.7603/s40706-013-0005-3

Buckley, R. (2007). Adventure tourism products: Price, duration, size, skill, remoteness. Tourism management, 28(3), 1428-1433. https://doi.org/10.1016/j.tourman.2006.12.003

Canadian tourism commission. (20I5). Canada millennial domestic travel summary report. Retrieved from https://www.destinationcanada.com/sites/default/files/2016-

I I/Programs_MillennialTravel_DomesticReport_EN.pdf

Cervone, D., \& Pervin, L. (2012). Kepribadian: Teori dan penelitian (2nd ed.). Jakarta: Salemba Humanika. 
Davies, G., Rojas-méndez, J. I., Whelan, S., Mete, M., Loo, T., Davies, G., \& Whelan, S. (2018). Brand personality: Theory and dimensionality. Journal of product \& brand management, 27(2), II5-I27. https://doi.org/I0.I I08/JPBM-06-20I7-I499

Fadil, M., \& Loeis, W. (2016). Struktur kepribadian. Research gate, 24-33. Retrieved from https://www.researchgate.net/publication/265274222

Farhan, A. (2012). Wamenparekraf: Wisata adalah kebutuhan. Retrieved January 6, 2019, from https://travel.detik.com/travel-news/d-1958370/wamenparekraf

-wisata-adalah-kebutuhan

Feist, J., \& Feist, G. J. (20I4). Teori kepribadian (7 Vol. II). Jakarta: Salemba Humanika.

Friedman, H. S., \& Schustack, M. W. (2008). Kepribadian teori klasik dan riset modern (Ist ed.). Jakarta: Erlangga.

Friedman, H. S., \& Schustack, M. W. (20I2). Personality: Classic theories and modern research (5th ed.). Boston: Pearson.

Gretzel, U., Mitsche, N., Hwang, Y.-H., \& Fesenmaier, D. R. (2004). Tell me who you are and i will tell you where to go: Use of travel personalities in destination recommendation systems. Information technology \& tourism, 7, 3-12. https://doi.org/10.3727//09830504278I I 29

Gurven, M., Rueden, C. Von, Massenkoff, M., Kaplan, H., \& Vie, M. L. (20I3). How universal is the big five? Testing the five-factor model of personality variation among forager-farmers in the Bolivian Amazon. Journal of personality and social psychology, 104(2), 354-370. https://doi.org//0.1037/a003084 I

Hill, B. J. (1995). A guide to adventure travel. Parks and recreation, 56-65.

Jani, D. (20I4a). Big five personality factors and travel curiosity: are they related? Anatolia, 25(3), 444-456. https://doi.org// 0.1080/I30329/7.2014.909366

Jani, D. (20 I4b). Relating travel personality to big five factors of personality. Tourism, 62(4), 347359.

John, O. P., \& Srivastava, S. (1999). The Big-Five trait taxonomy: History, measurement, and theoretical perspectives. In L. A. Pervin \& O. P. John (Eds.), Handbook of personality: Theory and research. New York: The Guilford Press.

Kalebos, F. (2016). Faktor-faktor yang mempengaruhi kepuasan wisatawan yang berkunjung ke daerah wisata Kepulauan. Jurnal riset bisnis dan manajemen, Vol.4(No.3), 489-502.

Larsen, R. J., \& Buss, D. M. (2002). Personality psychology: Domain of knowledge about human nature. New York: McGraw Hil.

Mastuti, E. (2005). Analisis faktor alat ukur kepribadian big five (Adaptasi dari IPIP) pada mahasiswa suku jawa. INSAN, 7(3).

Matthews, G., Deary, I. J., \& Whiteman, M. C. (2009). Personality Traits: Third Edition. New York: Cambridge University Press. 
McCrae, R. R., \& Costa, P. T. (2003). Personality in adulthood (2nd ed.). New York: The Guilford Press.

McCrae, R. R., Costa, P. T., Parker, W. D., Mills, C. J., Fruyt, F. De, \& Mervielde, I. (2003). Personality trait development from age 12 to age 18: Longitudinal, cross sectional, and cross-cultural analyses. Journal of personality and social psychology, 83(6), I456-1468. https://doi.org//0.1037//0022-35|4.83.6.1456

Mosonyi, A., Könyves, E., Fodor, I., \& Müller, A. (2013). Leisure activities and travel habits of college students in the light of a survey. Applied studies in agribusiness and commerce, 7, 5762. https://doi.org//0.1904I/Apstract/2013/1/10

Park, S., Tussyadiah, I. P., Mazanec, J., \& Fesenmaier, D. R. (2010). Travel personal of american pleasure travelers: A network analysis. Journal of travel \& tourism marketing, 27(8), 797-81 I. https://doi.org/10.1080/10548408.2010.527246

Pervin, L. A. (2003). The Science of Personality. New York: Oxford University Press.

Popescu, I.-V., \& Olteanu, V. (20I4). Luxury tourism: Characteristics and trends of the behavior of purchase. SEA - Practical application of science, II(2(4)), 319-324.

Pullmann, H., Raudsepp, L., \& Allik, Ju. (2006). Stability and change in adolescents ' personality: A longitudinal study. European journal of personality, 20(September), 447-459. https://doi.org/10.1002/per.61I

Ramdhani, N. (2012). Adaptasi bahasa dan budaya inventori big five. Jurnal psikologi, 39(2), I89207. https://doi.org/10.1016/S0I43-4004(97)9009/-6

Ryff, C. D. (1989). Happiness is everything, or is it? Explorations on the meaning of psychological well-being. Journal of Personality and Social Psychology, 57, 1069-1081.

Ryff, C.D.(1995). Psychological well-being in adult life. Current Directions in Psychological Science, 4, 99-104.

Schneider, P. P., \& Vogt, C. A. (2012). Applying the $3 \mathrm{M}$ model of personality and motivation to adventure travelers. Journal of travel research, 5I(6), 704-7I6.

Scott, K., \& Mowen, J. C. (2007). Travelers and their traits : A hierarchical model approach. Journal of consumer behaviour, 6, I46-157. https://doi.org/I0.1002/cb.214

Seyidov, J., \& Adomaitienè, R. (2016). Factors influencing local tourists ' decision-making on choosing a destination: A case of azerbaijan. Ekonomika, 95(3), II2-127. https://doi.org/10.15388/ekon.2016.3.10332

Sung, H., Morrison, A., Hong, G., \& O'Leary, J. (1996). Definition of adventure travel: conceptual framework for empirical application from the providers' perspective. Asia pacific journal of tourism research, I(2), 46-68. https://doi.org/I0.1080/I094I66970872I975

Swarbrooke, J., Beard, C., Leckie, S., \& Pomfret, G. (2003). Adventure tourism: The new frontier. Oxford: Butterworth-Heinemann. 
Tilley, S., \& Houston, D. (2016). The gender turnaround: Young women now travelling more than young men. Journal of transport geography, 54, 349-358.

https://doi.org//0.1016/j.jtrangeo.2016.06.022

Tran, X., Nguyen, B. L., \& Nguyen, M. C. (2015). Effects of the big five personality traits on tecreation types - The case of vietnam tourism. Travel and tourism research association: Advancing tourism research globally. Retrieved from https://scholarworks.umass.edu/cgi/viewcontent.cgi?article=1043\&context=tt

UNWTO, \& Wyse Travel Confederation. (2010). The power of youth travel. Madrid. Retrieved from http://cf.cdn.unwto.org/sites/all/files/pdf/amreports_vol2_thepowerofyouthtourism_eng_lw. pdf

Van der Merwe, P., Cini, F., \& Saayman, M. (20I5). Tourism students' knowledge and tenets towards ecotourism. Journal of teaching in travel \& tourism, 15, 74-91. https://doi.org//0.1080/15313220.2014.999737

Verma, V., Kumar, S., \& Chandra, B. (2017). Big five personality and tourist's intention to visit green hotels. Journal of cleaner production, 15(2), 79-87. https://doi.org/10.1016/j.jclepro.2017.10.047

Wulandari, A., \& Rehulina, M. (20/3). Hubungan antara lima faktor kepribadian (The big five personality) dengan makna hidup pada orang dengan human immunodeficiency virus. Jurnal psikologi klinis dan kesehatan mental, 2(I), 4I-47. 